\title{
Chemical constituents of Eisenia arborea Areschoug from Baja California Sur, México
}

\author{
Dora L. Arvizu ${ }^{1}$, Yoloxochitl E. Rodríguez ${ }^{1}$, Gustavo Hernández ${ }^{1}$ \& Jesús I. Murillo ${ }^{1}$ \\ ${ }^{1}$ Centro Interdisciplinario de Ciencias Marinas-IPN, Departamento Desarrollo de Tecnologías \\ Apdo. Postal 592. La Paz, B.C.S., México, 23000
}

\begin{abstract}
Samples of Eisenia arborea from Baja California Sur, México collected in November 2002 and March 2003 were studied. The following parameters were analyzed separately from blades and stipes: moisture, ash, mannitol, fat and crude fiber. Alginate was isolated and the following quality parameters were obtained: yield (22.4-23.3\%), color ( $>$ 4) and viscosity (793- 2,210 $\mathrm{m} \cdot \mathrm{Pa} \cdot \mathrm{s}$ in $1 \%$ solution). No significant differences were obtained between two months, except for viscosity and crude fiber. Significant differences were obtained when comparing blades and stipes in viscosity, mannitol, ash and fat, while for yield, moisture and crude fiber no significant differences were obtained. FTIR spectroscopy showed that alginate from $E$. arborea contained similar amounts of mannuroic and guluronic acids $(M / G \approx 1)$.
\end{abstract}

Key words: alginate, Eisenia arborea, guluronic acid, mannuroic acid, mannitol, fat, crude fiber.

\section{Constituyentes químicos de Eisenia arborea Areschoug de Baja California Sur, México}

RESUMEN. Se estudiaron muestras de Eisenia arborea de Baja California Sur, México, recolectadas en noviembre de 2002 y marzo de 2003. Se determinaron los siguientes parámetros en lámina y estipe: humedad, cenizas, manitol, grasas y fibra cruda. Se aisló el alginato y se obtuvieron los siguientes parámetros: rendimiento (22,4-23,3\%), color (> 4) y viscosidad (793-2.210 $\mathrm{m} \cdot \mathrm{Pa} \cdot \mathrm{s}$ en una solución al 1\%). No se encontraron diferencias significativas entre los dos meses, a excepción de la viscosidad y fibra cruda. Se obtuvieron diferencias significativas al comparar los resultados entre lámina y estipe en viscosidad, manitol, cenizas y grasas, mientras que en el rendimiento, humedad y fibra cruda no hubo diferencia significativa. El espectro FTIR mostró que los alginatos de E. arborea contenían una cantidad similar de ácidos manurónico y gulurónico $(\mathrm{M} / \mathrm{G} \approx 1)$.

Palabras clave: alginato, Eisenia arborea, ácido gulurónico, ácido manurónico, manitol, grasas, fibra cruda.

Corresponding author: Dora L. Arvizu (darvizu@ipn.mx)

\section{INTRODUCTION}

Marine algae are one of the main renewable resources of the Baja California Peninsula. One of the main groups is the Phaeophyta because of its abundance and high content of alginates, mannitol, iodine and fucoidan. In this group we found the species Macrocystis pyrifera (Linnaeus) C. Agardh and Sargassum spp, which have been widely studied. However, there is another kelp type and abundant species, Eisenia arborea Areschoug which has been very little studied. This species is distributed from British
Columbia, Canada (Druehl, 1970) to Magdalena Bay, Baja California Sur, México (Aguilar-Rosas et al., 1990). This kelp is found from the intertidal level to $34 \mathrm{~m}$ depth, forming dense beds in many rocky areas along the Pacific coast, and produces shade to understory algae (Spalding et al., 2003).

The main interest of brown seaweeds from an industrial point of view is their alginate content. Alginate is a polysaccharide found in the cell wall as structural component of the alga and it is used for its thickening, stabilizing, film-forming and 
gel-producing properties (Kelco, 1986; Lobban \& Harrison, 1994). The use of Eisenia arborea as food complement will depend on its chemical composition. It could be used for example as a food complement for poultry, cattle or even man (Marín et al., 2003). In most of the algae, alginate yield and other chemical compounds do not remain constant and we may expect some seasonal variation or differences depending on the part of the algae used. These variations may change from place to place and could be related to environmental parameters (Percival \& McDowell, 1967).

There is not enough published information about Eisenia arborea chemical composition or the alginate properties from it. The objective of this study was to determine some chemical constituents, alginate yield and quality from E. arborea from Magdalena Bay, B.C.S. and analyze its potential as raw material for alginate production.

\section{MATERIALS AND METHODS}

\section{Materials}

Samples of Eisenia arborea were collected in Punta El Cabito del Farallón (2433'24.4”N, 11206’07.1'W) near Magdalena Bay, in November 2002 and March 2003 between 10-15 m depth. Algae were obtained at random, using one square meter quadrat $(n=30)$. Plants were cut with a knife from the base of the holdfast. The population consisted of adult plants with a density of 19 plants $\cdot \mathrm{m}^{-2}$, with about the same size $(88.7-122.6 \mathrm{~cm})$ and weight $(633-748 \mathrm{~g}) . \mathrm{We}$ assume that our sample included reproductive and sterile plants.

\section{Alginate yield, viscosity and color}

Algae were separated into blades and stipes, dried directly in sunlight and milled to 30 mesh. Alginate extraction at the laboratory level was carried out according to the method proposed by Arvizu-Higuera et al. (2002). Alginate yield was calculated based on the initial dry weight of the sample. Apparent viscosity was measured in $1 \%$ alginate solution at $22^{\circ} \mathrm{C}$, using a viscosimeter Brookfiel LVT. Color was by comparison with color standard in a scale of 1 to 4 (Hernández-Carmona et al., 1999a).

\section{Chemical constituents}

The following methods were used: moisture by thermo balance; ashes by ignition in a furnace (AOAC,
1990); mannitol by fast oxidation of poliol with periodic acid (Larsen, 1978); fat by microwave-assisted process (MAP ${ }^{\mathrm{TR}}$ ), using a mixture of the solvents diethyl ether-acetone in proportion 2:1 (Paré et al., 1994) and crude fiber by acid and alkaline hydrolysis (Larsen, 1978).

All the experiments were carried out in triplicate. The average, standard error and confidence interval $( \pm \mathrm{SE}$ ), with a level of significance at $95 \%$ were computed. ANOVA was used to detect significant differences between the two samples and parts of the plant $(\mathrm{p}<0.05)$ and Tukey honest significant test was used for post-hoc comparison of means (Zar, 1999).

\section{Alginate composition by infrared spectroscopy}

For IR spectral analysis, the alginate samples obtained above (blade and stipe of November and March) were separately dissolved in distilled water $\left(5 \mathrm{mg} \cdot \mathrm{mL}^{-1}\right)$. Two milliliters of each solution were transferred to polyethylene molds and evaporated to dryness at $55^{\circ} \mathrm{C}$ for $12 \mathrm{~h}$. Each transparent alginate film was mounted between two papers cut in a convenient shape for analysis. The spectra were acquired in a spectrometer FTIR Nicolet Avatar 360. All IR spectra were obtained in transmission on the spectral range of $400-500 \mathrm{~cm}^{-1}$. Each spectrum was the average of 128 scans at $4 \mathrm{~cm}^{-1}$ resolution. The M/G ratio (Mannuronic/Guluronic) was estimated semiquantitatively by comparison of the relative intensity of the IR bands against a standard. The method of most probable base line was used to calculate the relative intensity of IR absorption bands.

The alginate used as standard was subjected to compositional analysis by ${ }^{1} \mathrm{H}-\mathrm{NMR}$ according with the protocol proposed by Grasdalen et al. (1979), and characterized by FTIR spectroscopy, as well. The sample for NMR was dissolved in $\mathrm{D}_{2} \mathrm{O}$. The spectrum was recorded at $300.13 \mathrm{MHz}$ with a Jeol FX-300 FT-NMR spectrometer (USA).

\section{RESULTS}

\section{Alginate yield, viscosity and color}

Alginate yield was not significantly different between structures nor between two months $(\mathrm{p}>0.05)$. Yield for blades was $22.9 \%$ in November and $22.7 \%$ in March. Yield for stipes was $23.3 \%$ in November and $22.4 \%$ in March (Fig. 1). Viscosity of alginates obtained was significantly different between blades and 

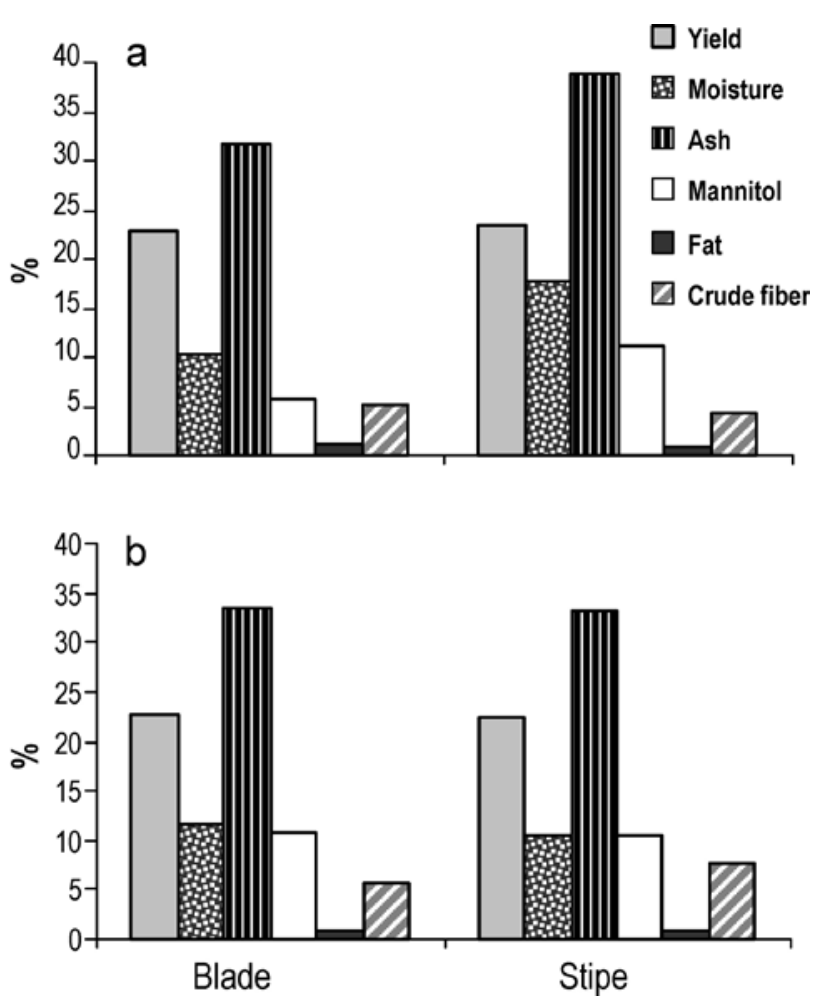

Figure 1. Alginate yield and chemical constituents from Eisenia arborea, a) collected in November 2002, b) collected in March 2003.

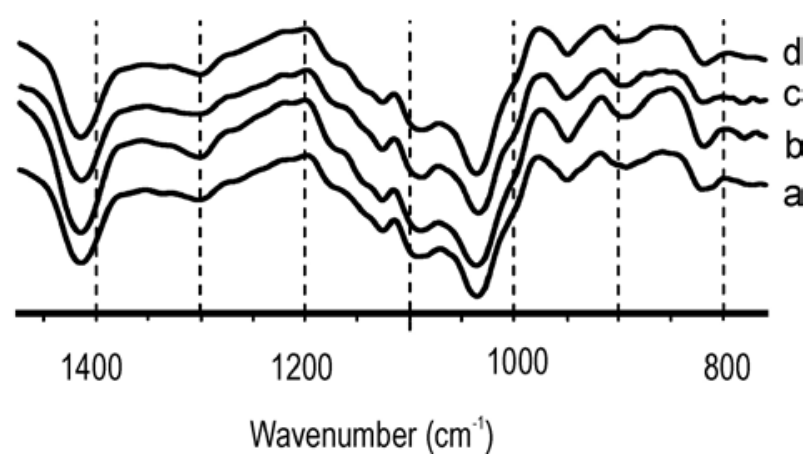

Figure 2. FTIR spectra $\left(1470-750 \mathrm{~cm}^{-1}\right)$ from alginate extracted from Eisenia arborea. Spectrum. a) alginate from stipes collected in November 2002, b) alginate from blades of November 2002, c) alginate from stipes of March 2003, d) alginate from blades of March 2003.

stipes ( $\mathrm{p}<0.05$ ). Alginate viscosity from blades was $37 \%$ higher than stipes during November, and 43\% higher than stipes in March. Alginate viscosity from stipes increased from November $(793 \pm 67.2 \mathrm{~m} \cdot \mathrm{Pa} \cdot \mathrm{s})$ to March $(1,260 \pm 236.3 \mathrm{~m} \cdot \mathrm{Pa} \cdot \mathrm{s})$, which represented a difference of $37 \%$. Alginate viscosity from blades increased from November $(1,270 \pm 143.3 \mathrm{~m} \cdot \mathrm{Pa} \cdot \mathrm{s})$ to March $(2,210 \pm 232.2 \mathrm{~m} \cdot \mathrm{Pa} \cdot \mathrm{s})$, which represented a difference of $42 \%$. In all cases, alginate color was higher than 4, according to the standards used, however alginate from stipes was slightly lighter than alginate from blades.

\section{Chemical constituents}

Results are shown in Fig. 1. Eisenia arborea moisture content after sun drying ranged from a maximum of $17.7 \%$ in stipes from November to a minimum of $10.4 \%$ on stipes from March. Moisture in blades 


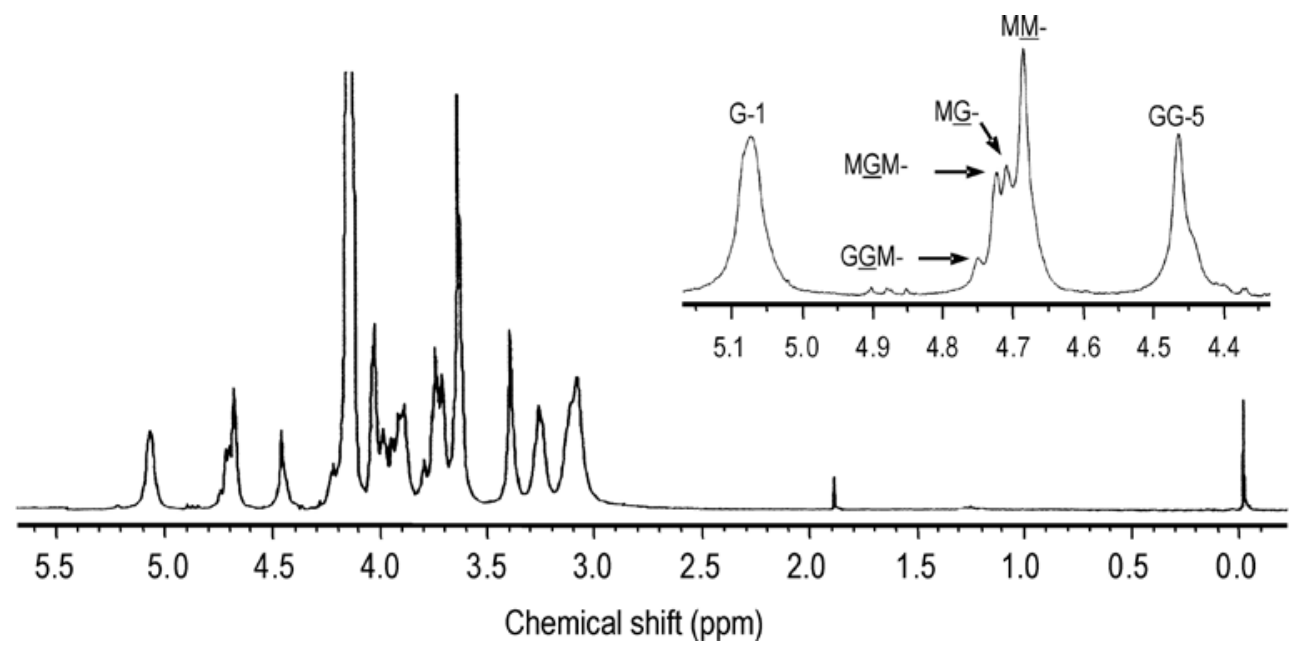

Figure 3. ${ }^{1} \mathrm{H}$-NMR spectrum of the alginate extracted from whole plants of Eisenia arborea collected in November 2002.

was not significantly different (10.4-11.7\%, p > $0.05)$. Ash content was not significantly different by sampling month, but it was different between structures in November (38.7\% in stipes and 31.8\% in blades). Mannitol content was significantly different $(\mathrm{p}<0.05)$ only between structures sampled from November. Maximum values were obtained on stipes $(11.1 \%)$ and minimum on blades $(5.7 \%)$. Fat content in November was significantly higher $(\mathrm{p}<$ $0.05)$ in blades $(1.28 \%)$ than stipes $(0.82 \%)$, while March samples were not significantly different $(\mathrm{p}>$ 0.05 ) in both structures (0.97 and $0.98 \%)$. Crude fiber from samples collected in March was significantly higher $(\mathrm{p}<0.05)$ in stipes $(7.7 \%)$ than blades $(5.7 \%)$. Crude fiber values in November were significantly lower ( $\mathrm{p}<0.05)$, ranging from $4.2 \%$ in stipe to $5.2 \%$ in blades.

\section{Alginate composition by infrared spectroscopy}

Figure 2 shows the dactiloscopic region (1,470-750 $\mathrm{cm}^{-1}$ ) of the IR spectra of the blades from November (B-Nov), stipes from November (S-Nov), blades from March (B-Mar), and stipes from March (SMar). The four spectra showed absorption bands that correspond to bands assigned to sodium alginate. Table 1 shows the comparison of the relative intensity of IR bands from our samples against the relative intensity of bands of an alginate with a known M/G ratio, this suggest that the $\mathrm{M} / \mathrm{G}$ ratio for our samples was about 1 . The ${ }^{1} \mathrm{H}-\mathrm{NMR}$ spectrum of the alginate (Fig. 3) used as standard showed frequencies of mannuronic and guluronic acids to be 0.52 and 0.48 , respectively. The $\mathrm{M} / \mathrm{G}$ ratio was 1.08 , and the length of the monoguluronic blocks was 7 units.

Using the comparison of relative intensities of IR bands of alginates is a semi-quantitative approach, so it was not possible to detect differences of $\mathrm{M} / \mathrm{G}$ ratio from seasons or structures, because the differences were very low (Table 1).

\section{DISCUSSION}

Alginate yield was lower that obtained by HernándezCarmona (1985) (24.6-28.6\%) with the same species and collected at a location close to our sampling area, however, he did not find either a significant seasonal variation of alginate yield. The yield obtained in this study was lower than in Eisenia bicyclis (Kjellman) Setchell with 34\% (Asakawa et al., 1984).

The alginate viscosity in March for blades was double the viscosity reported for Macrocystis pyrifera with 1,016 m·Pa.s (Hernández-Carmona et al., $1999 b)$. Since alginate is a structural polysaccharide, this may explain the high resistance of Eisenia arborea to strong currents and swell common in Magdalena Bay, which are stronger in winter (Martínez-López \& Verdugo-Díaz, 2000).

The alginate color obtained from Eisenia arborea was dark brown, and gave a higher value that commercial standard (1-4). However, the color could be improved using an additional step of bleaching in the extraction process of alginate, as it is generally carried out at the industrial level. 
Table 1. Relative intensity of FTIR bands from sodium alginate extracted from different parts of Eisenia arborea with reference to the carboxylate band at $1,610 \mathrm{~cm}^{-1}$

\begin{tabular}{cccccc}
\hline & \multicolumn{5}{c}{ a Relative intensity of FTIR bands } \\
\cline { 2 - 6 } Band \\
\cline { 2 - 6 }$\left(\mathbf{c m}^{-1}\right)$ & Bovember 2002 & \multicolumn{3}{c}{ March 2003 } \\
\hline 1,414 & 0.44 & 0.45 & 0.55 & 0.44 & 0.45 \\
1,300 & 0.05 & 0.05 & 0.05 & 0.04 & 0.05 \\
1,180 & 0.01 & 0.02 & 0.02 & 0.01 & 0.02 \\
1,150 & 0.01 & 0.01 & 0.01 & 0.01 & 0.01 \\
1,130 & 0.08 & 0.09 & 0.10 & 0.08 & 0.09 \\
1,090 & 0.12 & 0.13 & 0.20 & 0.11 & 0.14 \\
950 & 0.08 & 0.08 & 0.11 & 0.08 & 0.09 \\
890 & 0.05 & 0.05 & 0.04 & 0.04 & 0.05 \\
820 & 0.08 & 0.07 & 0.09 & 0.07 & 0.07 \\
\hline
\end{tabular}

${ }^{a}$ The relative intensity of bands was calculated by dividing the absorbance of each band by the absorbance of the band at $1,610 \mathrm{~cm}^{-1}$

${ }^{\mathrm{b}}$ Alginate standard, extracted from the whole plants of E. arborea, with a M/G ratio of 1.08 determined by ${ }^{1}$ H-NMR spectroscopy

The moisture of all samples was under the maximum moisture recommended (12\%), except for the stipes from November. It means that alga drying was enough to avoid decomposition so it can be transported and stored for long time periods.

Ash values obtained in November and March for stipes and blades were similar to values obtained for Eisenia bicyclis (33.2\%) (Asakawa et al., 1984). In general, ash content is always reported as high content in other brown algae (Larsen, 1978; Kelco, 1986; Rodríguez-Montesinos \& Hernández-Carmona, 1991; Pérez-Reyes, 1997).

Mannitol changes are correlated with plant growth and reproductive condition (Lobban \& Harrison, 1994). The highest value for Eisenia arborea was obtained in March; however it is lower than in E. bicyclis (12.9\%) (Asakawa et al., 1984), but it was higher than Macrocystis pyrifera in winter (7.3-8.2\%) (Rodríguez-Montesinos \& HernándezCarmona, 1991).

In general, the fat content in brown algae is very low. For this study, the values were similar to other genus like Laminaria (0.2-3\%) (Chapman \& Chapman, 1980) and Macrocystis (0.5-2.3\%) (Ortega-Ceseña \& Zaragoza-García, 1983; Kelco, 1986; Rodríguez-Montesinos \& Hernández-Carmona, 1991).

The values of crude fiber in this study were higher than obtained in Eisenia bicyclis (1.6\%) (Asakawa et al., 1984), but similar to Ascophyllum nodosum (Linnaeus) Le Jolis (5\%) and Laminaria digitata (Hudson) J.V. Lamouroux (7\%) (Guiry \& Blunden, 1991).

The alginate IR spectra showed absorptions which were consistent with sodium alginate extracted from Laminaria hyperborea. Sodium alginate can easily be distinguished from calcium alginate because differences into band shift (Sartori et al., 1997). In addition to the cation content, the mannuronic/guluronic proportion can be inferred in a semi-quantitative approach from the relative intensity ratio of characteristic IR bands. In general, alginate with high content of guluronic units produced more intense bands (Table 1) than alginate with medium content of guluronic units (Sartori et al., 1997; Pereira et al., 2003). NMR methods are the best in order to determine the detailed compositional data of alginate samples, but these methods are high in cost. The infrared spectroscopy presents four main advantages: it is not as expensive as NMR methods, it is fast, non-destructive, and it requires small sample quantities, which makes it quite convenient for rapid characterization of cation content and M/G proportion in alginate. Unfortunately, no obvious differences can be observed in the IR spectra as a function of molecular weight or length of monoblocks. 
This study gives us basic information about Eisenia arborea, abundant species in the Baja California Peninsula coasts. According the results obtained the blades had better quality of alginate, however, a more detailed study is needed, manly about its biomass to get a reliable conclusion if this specie could be exploited for commercial use.

\section{ACKNOWLEDGEMENTS}

The authors are grateful to Instituto Politécnico Nacional (CICIMAR-IPN) for the financial support. We are grateful to the "Comisión para el Fomento de Actividades Académicas del Instituto Politécnico Nacional (COFAA-IPN)" and the Program "Estímulo al Desempeño de la Investigación (EDI-IPN)" for the fellowship received. We thank to "Dirección de Servicios Periciales de la Procuraduría General de Justicia" of Baja California Sur State, for allow us to use the FTIR spectrophotometer equipment. We thank to Kim Siewers for English edition.

\section{REFERENCES}

Aguilar-Rosas, R., L.E. Aguilar-Rosas \& N.A. Ramos-Jardón. 1990. Análisis biogeográfico del orden Laminariales (Phaeophyta) en las costas de la península de Baja California, México. Inv. Mar. CICIMAR, 5(2): 107-121.

Association of Official Analysis Chemists (AOAC). 1990. Official methods of analysis. Washington, D.C., $1141 \mathrm{pp}$.

Arvizu-Higuera, D.L., G. Hernández-Carmona \& Y.E. Rodríguez-Montesinos. 2002. Parameters affecting the conversion of alginic acid to sodium alginate. Cienc. Mar., 28(1): 27-36.

Asakawa, A., K. Ohwada \& N. Tanaka. 1984. The seasonal variation in chemical composition of several brown algae, Eisenia bicylis, Sargassum horneri, Sargassum piluriferum and Hydroclathrus clathratus, collected at Ago Bay. Bull. Natl. Res. Inst. Aquacult. Japan, 6: 65-69.

Chapman, V.J. \& D.J. Chapman. 1980. Seaweed and their uses. Chapman \& Hall, London, 334 pp.

Druehl, L.D. 1970. The pattern of Laminariales distribution in the northeast Pacific. J. Phycol., 9(3/4): 237-247.

Grasdalen, H., B. Larsen \& O. Smidsrød. 1979. PMR study of the composition and sequence of urinate residues in alginates. Carbohydr. Res., 68(1): 23-31.

Guiry, D. \& G. Blunden. 1991. Seaweed resource in Europe: uses and potential. John Wiley \& Sons, Chichester, 430 pp.

Hernández-Carmona, G. 1985. Variación estacional del contenido de alginatos en tres especies de feofitas de Baja California Sur. Inv. Mar. CICIMAR, 2(1): 29-45.

Hernández-Carmona, G., D.L. Arvizu-Higuera \& Y.E. Rodríguez-Montesinos. 1999a. Manual de técnicas de control de calidad para el ácido algínico y sus derivados. CICIMAR-IPN. La Paz, B.C.S., México, 20 pp.

Hernández-Carmona, G., D.J. McHugh \& F. LópezGutiérrez. 1999b. Pilot plant scale extraction of alginate from Macrocystis pyrifera. 2. Studies on extraction conditions and methods of separating the alkaline-insoluble residue. J. Appl. Phycol., 11(6): 493-502.

Kelco. 1986. Algin hydrophilic derivatives of alginic acid for scientific water control. Kelco Division of Merck, San Diego, California, 56 pp.

Larsen, B. 1978. Brown seaweeds: analysis of ash, fiber, iodine and mannitol. In: J.A. Hellebust \& J.S. Craigie (eds.). Handbook of phycological methods. Cambridge University Press, Cambridge, pp. 181-188.

Lobban, C.S. \& P.J. Harrison. 1994. Seaweed ecology and physiology. Cambridge University Press, Cambridge, 366 pp.

Marín, A., M. Casas, S. Carrillo, H. Hernández \& A. Monroy. 2003. Performance of sheep fed rations with Sargassum spp. sea algae. Cuban J. Agric. Sci., 37(2): 119-123.

Martínez-López, A. \& G. Verdugo-Díaz. 2000. Composición y dinámica del fitoplancton en el BAC de Bahía Magdalena, B.C.S. In: D. Lluch-Belda, J. Elorduy-Garay, S.E. Lluch-Cota \& G. Ponce-Díaz (eds.). BAC: centros de actividad biológica del Pacífico mexicano. CIBNOR, CICIMAR, CONACYT, México, pp. 125-142.

Ortega-Ceseña, G. \& A. Zaragoza-García. 1983. Determinación de los parámetros de extracción de ácido algínico del alga café Macrocystis pyrifera. Bachelor Thesis, Universidad Autónoma de Baja California, 103 pp.

Paré, J.R.J., J.M.R. Bélanger \& S.S. Stanford. 1994. Microwave-assisted process (MAP ${ }^{\mathrm{TM}}$ ): a new tool for the analytical laboratory. Trends Anal. Chem., 13(4): 176-184. 
Percival, E. \& R.H. McDowell. 1967. Chemistry and enzymology of marine algal polysaccharides. Academic Press, London, 219 pp.

Pereira, L., A. Sousa, H. Coelho, A.M. Amado \& P.J.A. Riveiro-Claro. 2003. Use of FTIR, FT-Raman and ${ }^{13} \mathrm{C}$-NMR spectroscopy for identification of some seaweed phycocolloids. Biomol. Eng., 20(4-6): 223-228.

Pérez-Reyes, C. 1997. Composición química de Sargassum spp. colectado en la bahía de La Paz, B.C.S., y la factibilidad de su aprovechamiento en forma directa o como fuente de alginato. MSc. Thesis. CICIMAR-IPN, México, 76 pp.
Rodríguez-Montesinos, Y.E. \& G. Hernández-Carmona. 1991. Seasonal and geographic variations of Macrocystis pyrifera chemical composition at the western coast of Baja California. Cienc. Mar., 17(3): 91-107.

Sartori, C., D.S. Finch, B. Ralph \& K. Gilding. 1997. Determination of the cation content of alginate thin films by FT-IR spectroscopy. Polymer, 38(1): 43-51.

Spalding, H., M.S. Foster \& J.N. Heine. 2003. Composition distribution, and abundance of depth-water ( $>30 \mathrm{~m}$ ) macroalgae in central California. J. Phycol., 39(2): 273-284.

Zar, J.H. 1999. Biostatistical analysis. Prentice-Hall, New Jersey, 663 pp.

Received: 12 February 2007; Accepted: 6 September 2007 